\title{
Streptococcus henryi sp. nov. and Streptococcus caballi sp. nov., isolated from the hindgut of horses with oligofructose-induced laminitis
}

\author{
Gabriel J. Milinovich, ${ }^{1}$ Paul C. Burrell, ${ }^{2}$ Christopher C. Pollitt, ${ }^{1}$ \\ Anne Bouvet ${ }^{3}$ and Darren J. Trott ${ }^{1}$ \\ ${ }^{1}$ Australian Equine Laminitis Research Unit, School of Veterinary Science, The University of \\ Queensland, Brisbane, Queensland 4072, Australia \\ ${ }^{2}$ Biosecurity Sciences Laboratory, Department of Primary Industries and Fisheries, Brisbane, \\ Queensland 4001, Australia \\ ${ }^{3}$ Centre National de Référence des Streptocoques, Service de Microbiologie, Hôtel Dieu, AP-HP, \\ Université René Descartes, Paris 5, France
}

Correspondence

Gabriel J. Milinovich

g.milinovich@uq.edu.au

\begin{abstract}
Four Gram-positive, catalase-negative, coccoid-shaped isolates were obtained from the caecum and rectum of horses with oligofructose-induced equine laminitis. Phenotypic and phylogenetic studies were performed on these isolates. Initial biochemical profiling assigned two of the isolates to Streptococcus bovis. The other two isolates, however, could not be assigned conclusively on the basis of their biochemical profiles. Gene sequence analysis demonstrated that the four new isolates were related most closely to Streptococcus suis based on the 16S rRNA gene and to Streptococcus orisratti based on the manganese-dependent superoxide dismutase gene $(\operatorname{sod} A)$. Sequence divergence values from recognized Streptococcus species based on these two genes were $>3$ and $>13 \%$, respectively, for all four isolates. Phylogenetic and phenotypic analyses demonstrated that the four isolates formed two distinct clonal groups that are suggested to represent two novel species of the genus Streptococcus. The names proposed for these organisms are Streptococcus henryi sp. nov. (type strain $126^{\top}=$ ATCC BAA-1484 $^{\top}=\mathrm{DSM}$ $19005^{\top}$ ) and Streptococcus caballi sp. nov. (type strain $151^{\top}=$ ATCC BAA-1485 ${ }^{\top}=\mathrm{DSM}$ $\left.19004^{\top}\right)$.
\end{abstract}

Equine laminitis is defined most simply as a failure of attachment between the distal phalanx and the inner hoof wall (Pollitt, 1999) and is considered to be the most serious disease of the equine foot. Laminitis is frequently attributable to dietary intake of excess carbohydrate in the form of lush pasture ( $45.6 \%$ excess) or grain $(7.4 \%)$ (USDA, 2000), with such exposure resulting in significant population shifts in the equine hindgut microbiota, from one dominated by Gram-negative organisms to one dominated by Gram-positive organisms. By using the oligofructose-induction model of van Eps \& Pollitt (2006), streptococci of the Streptococcus bovis/equinus complex have been demonstrated to routinely become established in the caecum as the dominant morphotype by as early as $2 \mathrm{~h}$ after oligofructose administration (Milinovich et al., 2007).

The GenBank/EMBL/DDBJ accession numbers for the 16S rRNA and sodA gene sequences of strain $151^{\top}$ are EF364098 and EF364100, respectively, and of strain $126^{\top}$ are EF364097 and EF364099, respectively.

An extended 16S rRNA gene sequence-based phylogenetic tree is available as a supplementary figure with the online version of this paper.
Although it is accepted that microbial changes occurring in the equine hindgut represent the initiating event for the foot pathology observed with laminitis, the mechanisms by which this pathology occurs and the factors responsible for triggering them remain to be elucidated (Garner et al., 1975, 1978; Pollitt, 1996). This paper describes the phenotypic and genotypic characteristics of four streptococcal isolates obtained from the hindgut of horses in which laminitis was experimentally induced. We propose that these isolates represent two novel species of the genus Streptococcus.

Laminitis was induced in two horses by administration of a bolus dose of oligofructose, as described previously by van Eps \& Pollitt (2006). Preliminary 16S rRNA gene sequence analysis of four isolates recovered on incubated equine caecal fluid agar (Milinovich et al., 2006) revealed them to represent novel streptococci, and these isolates were characterized further. Two of the four isolates, 120 and $126^{\mathrm{T}}$, were recovered from the caecum of a caecally fistulated horse at 32 and $40 \mathrm{~h}$ after oligofructose induction, respectively. Isolates 148 and $151^{\mathrm{T}}$ were 
recovered from faeces collected per rectum at 16 and $24 \mathrm{~h}$ after oligofructose administration, respectively (Milinovich et al., 2006). The new isolates were Gram-stained, assessed for the presence of catalase and subjected to Lancefield grouping by using group A-, B-, C-, D-, F- and G-specific streptococcal latex agglutinating antisera (Oxoid). The ability of the isolates to tolerate the presence of $6.5 \% \mathrm{NaCl}$, $0.016 \%$ potassium tellurite and $40 \%$ bile was assessed (Swan, 1954), and biochemical profiling was performed on all four isolates by using the commercially available API 20 Strep and Rapid ID32 Strep kits (bioMérieux). The phylogenetic position of the four isolates was determined through sequence analysis of the 16S rRNA and manganese-dependent superoxide dismutase $(\operatorname{sod} A)$ genes. Amplification of the 16S rRNA gene was performed by using primers $27 \mathrm{f}$ ( $5^{\prime}$-AGAGTTTGATCMTGGCTCAG-3') and $1492 \mathrm{r}$ (5'-TACGGYTACCTTGTTACGACTT- $\left.3^{\prime}\right)$ (Lane, 1991) and the cycle parameters described by Burrell et al. (1998). Amplification of the sodA gene was performed by using the cycle parameters and primers sodA-F (5'-TRCAYCATGAYAARCACCAT- $\left.3^{\prime}\right)$ and sodA$\mathrm{R}$ (5'-ARRTARTAMGCRTGYTCCCARACRTC- $\left.3^{\prime}\right)$ of Hoshino et al. (2005). All PCRs described were performed by using high-fidelity DNA polymerase (iProof highfidelity DNA polymerase; Bio-Rad). PCR products were purified by using a QIAquick PCR purification kit (Qiagen) and sequencing was performed with a BigDye Terminator (version 3.1) sequencing kit (Applied Biosystems). In addition to the primers $27 \mathrm{f}$ and $1492 \mathrm{r}$, primers $803 \mathrm{f}$ ( $5^{\prime}$-ATTAGATACCCTGGTAG-3') (Stackebrandt \& Charfreitag, 1990) and 907r (5'-CCGTCAATTCMTTTRAGTTT- $\left.3^{\prime}\right)$ (Lane, 1991) were used in sequencing reactions to obtain near full-length sequences for the $16 \mathrm{~S}$ rRNA gene. Sequencing of the sodA gene was performed by using the primers sodA-F and sodA-R described above. An ABI PRISM 3130xl Genetic Analyzer (Applied Biosystems) was used for sequencing. Sequence and phylogenetic analyses were performed as described by Bjornsson et al. (2002).

Cells of the four new isolates were non-motile, catalasenegative, Gram-positive cocci. They were able to tolerate the presence of $40 \%$ bile and $0.016 \%$ potassium tellurite, but not $6.5 \% \mathrm{NaCl}$. Isolates 120 and $126^{\mathrm{T}}$ reacted with Lancefield group D-specific streptococcal antisera, whereas isolates 148 and $151^{\mathrm{T}}$ were unreactive to all tested antisera. Isolates 120 and $126^{\mathrm{T}}$ shared the same biochemical profile, as did isolates 148 and $151^{\mathrm{T}}$. Isolates 120 and $126^{\mathrm{T}}$ produced numerical profiles of 4250533 and 62236063110 for the API 20 Strep and Rapid ID32 Strep kits, respectively. The respective numerical profiles for isolates 148 and $151^{\mathrm{T}}$ were 5240073 and 22063063110 . Isolates 148 and $151^{\mathrm{T}}$ were identified by the two kits as representing $S$. bovis. By contrast, the API 20 Strep and API Rapid ID32 Strep kits produced conflicting results for isolates 120 and $126^{\mathrm{T}}$, identifying them as representing $S$. suis and Globicatella sanguinis, respectively.

In accordance with the biochemical profiles, $16 \mathrm{~S}$ rRNA and sodA gene sequence analysis identified isolates 120 and $126^{\mathrm{T}}$ as clones distinct from isolates 148 and $151^{\mathrm{T}}$. Isolates 120 and $126^{\mathrm{T}}$ were determined by BLAST analysis to have highest sequence similarity to the type strain of S. suis $(96.4 \%)$ based on the 16S rRNA gene and to that of Streptococcus orisratti ( $86.6 \%$ ) based on the sodA gene. Isolates 148 and $151^{\mathrm{T}}$ were determined to be related most closely to the type strain of S. suis $(96.8 \%)$ based on the 16S rRNA gene and that of $S$. orisratti $(83.4 \%)$ based on the sodA gene. Sequence divergence between the two groups of isolates was $4.1 \%$ for the $16 \mathrm{~S}$ rRNA gene and $14.7 \%$ for the sodA gene. The DNA $\mathrm{G}+\mathrm{C}$ content was assayed for isolates $126^{\mathrm{T}}$ and $151^{\mathrm{T}}$ at the DSMZ by using the HPLC method of Mesbah et al. (1989) and was determined to be 38.7 and $46.8 \mathrm{~mol} \%$, respectively.

Phylogenetic analyses were performed as described in Bjornsson et al. (2002). In brief, one parsimonious and three distance analyses were performed on a neighbourjoining tree to generate bootstrap values, and the summary of these four analyses (with bootstrap values of over $70 \%$ ) is illustrated in a $16 \mathrm{~S}$ rRNA gene sequence-based phylogenetic tree (Fig. 1; an extended version of this tree is available as Supplementary Fig. S1 in IJSEM Online). The topology of this phylogenetic tree, together with comparative $16 \mathrm{~S}$ rRNA gene sequence analysis, gave divergence values of $>3 \%$ between the new isolates and their nearest recognized relatives (Stackebrandt \& Goebel, 1994). These data support the recognition of these two streptococcal groups of isolates as representing two novel and distinct species. sodA gene sequence analysis, which has been demonstrated to be a useful means of differentiating streptococci on phylogenetic grounds (Poyart et al., 1998, 2002), demonstrated divergence values of $>13 \%$ between the new isolates and their nearest recognized relatives (not shown), further supporting this finding. A BLAST analysis revealed that the closest relative to the two groups of isolates was the type strain of S. suis, which is supported by phylogenetic analysis (Fig. 1), illustrating that $S$. suis is the closest relative based on branch lengths and phylogenetic positioning. 16S rRNA gene sequence similarity matrix analyses (data not shown) also revealed that the two groups of isolates showed $95.7 \%$ similarity to each other, further supporting the hypothesis that these represent two distinct and novel streptococcal species. Tests which are useful for differentiating strains $126^{\mathrm{T}}$ and $151^{\mathrm{T}}$ from closely related species are shown in Table 1.

On the basis of the data presented, we conclude that the four novel strains represent two novel species of the genus Streptococcus, for which the names Streptococcus henryi sp. nov. and Streptococcus caballi sp. nov. are proposed.

\section{Description of Streptococcus henryi sp. nov.}

Streptococcus henryi [hen.ry'i. N.L. gen. $\mathrm{n}$. henryi named in honour of Dr Dick Peter Henry (AM) (1924-2003), a highly respected Australian veterinarian and microbiologist].

Cells are Gram-positive, non-motile ovoids, typically occurring in pairs or short chains. When grown anaerobically for $24 \mathrm{~h}$ on sheep blood agar, colonies are round, flat, shiny, $2 \mathrm{~mm}$ in diameter, off-white in colour and exhibit 


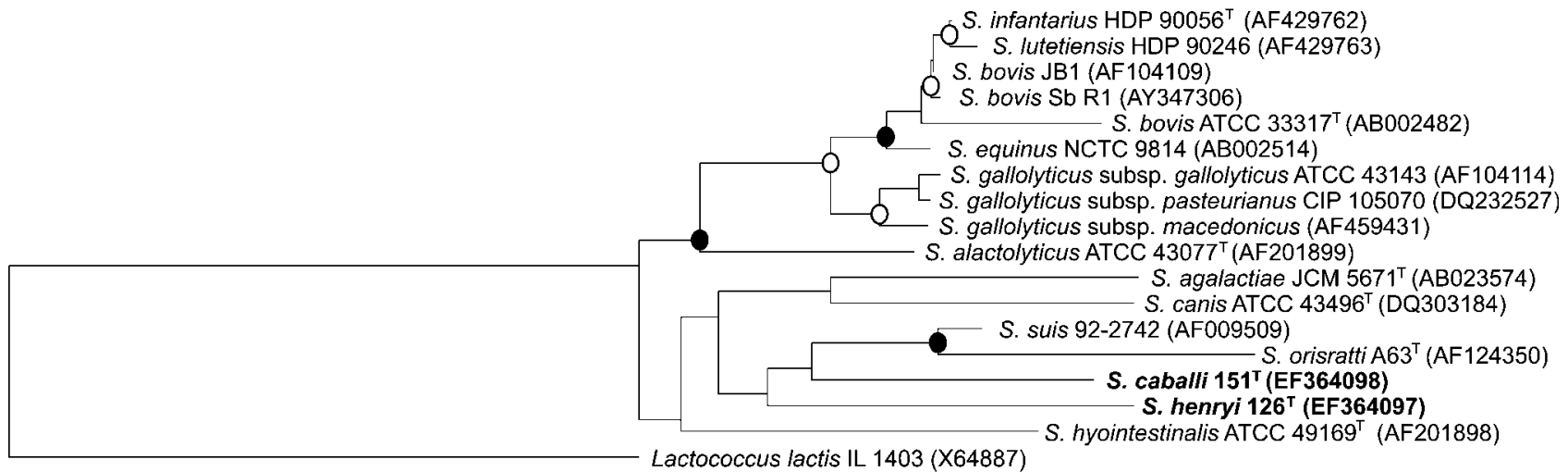

0.10

Fig. 1. Phylogenetic tree showing the positions of strains $126^{\top}$ and $151^{\top}$ and their closest relatives based on $16 \mathrm{~S}$ rRNA gene sequences. All four of the new isolates were fully sequenced; however, only one representative of each of the novel species described is illustrated in this phylogenetic tree as the two isolates for each species had identical 16S rRNA gene sequences. Closed circles indicate that bootstrap values were $>70 \%$ (of 1000 trees) in all four distance and parsimonious analyses, whereas open circles indicate that bootstrap values were $>70 \%$ (based on 1000 trees) in three of the four distance and parsimonious analyses. Bar, 10 substitutions per 100 nucleotides. An extended version of this tree is available as Supplementary Fig. S1 in IJSEM Online.

$\alpha$-haemolysis. Cells are facultatively anaerobic and catalasenegative. Cells react to streptococcal group D antisera and are able to grow in the presence of $40 \%$ bile and $0.016 \%$ potassium tellurite, but do not grow in the presence of $6.5 \%$ $\mathrm{NaCl}$. In API 20 Strep and Rapid ID32 Strep kits, cells are able to produce acid from starch, glycogen, inulin, lactose,

Table 1. Tests useful in distinguishing strains $126^{\top}$ and $151^{\top}$ from closely related species of the genus Streptococcus

Taxa: 1, strain $126^{\mathrm{T}}$ (identical results for strain 120); 2, strain $151^{\mathrm{T}}$ (identical results for strain 148); 3, S. bovis; 4, S. equinus; 5, S. lutetiensis; 6, S. infantarius; 7, S. gallolyticus subsp. gallolyticus; 8, S. gallolyticus subsp. macedonicus; 9, S. gallolyticus subsp. pasteurianus; 10, S. alactolyticus; 11, S. suis. Results for strains $126^{\mathrm{T}}$ and $151^{\mathrm{T}}$ were obtained by using API Strep 20 and Rapid ID 32 Strep kits. Data for reference species are from Chatellier et al. (1998), Facklam (2002), Kilpper-Bälz \& Schleifer (1987), Schlegel et al. (2003, 2004) and Tarradas et al. (1994). +, Positive; -, negative; V, variable; NG, non-groupable; ND, no data available.

\begin{tabular}{|c|c|c|c|c|c|c|c|c|c|c|c|}
\hline Characteristic & 1 & 2 & 3 & 4 & 5 & 6 & 7 & 8 & 9 & 10 & 11 \\
\hline \multicolumn{12}{|l|}{ Lancefield antigen group: } \\
\hline $\mathrm{D}$ & + & - & + & + & $\mathrm{V}$ & $\mathrm{V}$ & $\mathrm{V}$ & $\mathrm{V}$ & $\mathrm{V}$ & $\mathrm{V}$ & $\mathrm{v}$ \\
\hline Other & - & - & - & - & - & - & - & - & - & - & $\mathrm{R}, \mathrm{RS}, \mathrm{S}, \mathrm{T}$ or $\mathrm{NG}$ \\
\hline \multicolumn{12}{|l|}{ Production of: } \\
\hline Acetoin (Voges-Proskauer) & - & + & + & + & + & + & + & + & + & + & - \\
\hline$\beta$-Glucosidase & + & + & + & + & + & $\mathrm{V}$ & + & - & + & + & $\mathrm{v}$ \\
\hline$\beta$-Glucuronidase & - & - & - & - & - & - & - & - & + & - & + \\
\hline$\alpha$-Galactosidase & + & + & + & - & + & + & + & $\mathrm{V}$ & $\mathrm{V}$ & + & $\mathrm{v}$ \\
\hline$\beta$-Galactosidase ( $\beta$-GAR) & + & - & - & - & - & - & - & + & - & - & $\mathrm{ND}$ \\
\hline$\beta$-Galactosidase $(\beta$-GAL) & + & - & - & - & - & - & - & $\mathrm{V}$ & + & - & $\mathrm{V}$ \\
\hline$\beta$-Mannosidase & - & - & - & - & - & - & $\mathrm{V}$ & - & + & - & ND \\
\hline Hydrolysis of aesculin & + & + & + & + & + & $\mathrm{V}$ & + & - & + & + & + \\
\hline \multicolumn{12}{|l|}{ Acid from: } \\
\hline Glycogen & + & + & + & - & - & + & + & - & - & - & + \\
\hline Inulin & + & + & + & - & - & - & + & - & - & - & $\mathrm{v}$ \\
\hline Lactose & + & - & + & - & + & + & + & + & + & - & + \\
\hline Mannitol & + & - & - & - & - & - & + & - & - & - & - \\
\hline Methyl $\beta$-D-glucopyranoside & + & + & + & + & + & - & + & - & + & $\mathrm{V}$ & ND \\
\hline Raffinose & - & + & + & - & - & + & + & - & $\mathrm{V}$ & - & $\mathrm{v}$ \\
\hline Trehalose & + & + & $\mathrm{v}$ & $\mathrm{V}$ & - & - & + & - & + & - & + \\
\hline
\end{tabular}


maltose, mannitol, melibiose, methyl $\beta$-D-glucopyranoside, pullulan, sucrose and trehalose, but not from $\mathrm{D}$-arabinose, $\mathrm{L}-$ arabinose, cyclodextrin, melezitose, raffinose, ribose, sorbitol or tagatose. Cells do not produce acetoin (VogesProskauer-negative) or hydrolyse arginine or hippurate, but do hydrolyse aesculin. Positive for alanyl-phenylalanylproline arylamidase, $\alpha$-galactosidase, $\beta$-galactosidase, $\beta$ glucosidase and leucine aminopeptidase, but negative for $N$-acetyl- $\beta$-glucosaminidase, alkaline phosphatase, $\beta$-glucuronidase, glycyl tryptophan arylamidase, $\beta$-mannosidase, pyrrolidonyl arylamidase and urease. The DNA G $+\mathrm{C}$ content of the type strain is $38.7 \mathrm{~mol} \%$.

The type strain, $126^{\mathrm{T}} \quad\left(=\mathrm{ATCC}\right.$ BAA- $1484^{\mathrm{T}}=\mathrm{DSM}$ $\left.19005^{\mathrm{T}}\right)$, was isolated from the caecum of a horse with oligofructose-induced laminitis.

\section{Description of Streptococcus caballi sp. nov.}

Streptococcus caballi (ca.bal'li. L. gen. n. caballi of an inferior riding- or pack-horse; named in recognition of the domestic horse, Equus caballus, which, of the seven species of Equidae, suffers most from laminitis).

Cells are Gram-positive, non-motile ovoids, typically occurring in pairs or chains commonly over 20 cells long. Anaerobic growth for $24 \mathrm{~h}$ on sheep blood agar produces flat, shiny, off-white, round, $\alpha$-haemolytic colonies, $1-$ $2 \mathrm{~mm}$ in diameter. Colonies have a tendency to imbed into sheep blood agar. Cells are facultatively anaerobic and catalase-negative. Cells do not react with streptococcal group A-, B-, C-, D-, F- or G-specific antisera. Cells are able to grow in the presence of $40 \%$ bile and $0.016 \%$ potassium tellurite, but not $6.5 \% \mathrm{NaCl}$. In API 20 Strep and Rapid ID32 Strep kits, cells are able to produce acid from starch, glycogen, inulin, maltose, melibiose, methyl $\beta$ D-glucopyranoside, pullulan, raffinose, sucrose and trehalose, but not from D-arabinose, L-arabinose, cyclodextrin, lactose, mannitol, melezitose, ribose, sorbitol or tagatose. Cells do not hydrolyse arginine or hippurate, but do hydrolyse aesculin and are able to produce acetoin (VogesProskauer-positive). Positive for alanyl-phenylalanyl-proline arylamidase, $\alpha$-galactosidase, $\beta$-glucosidase and leucine aminopeptidase, but negative for $N$-acetyl- $\beta$-glucosaminidase, alkaline phosphatase, $\beta$-galactosidase, $\beta$-glucuronidase, glycyl tryptophan arylamidase, $\beta$-mannosidase, pyrrolidonyl arylamidase and urease. The DNA G+C content of the type strain is $46.8 \mathrm{~mol} \%$.

The type strain, $151^{\mathrm{T}} \quad\left(=\mathrm{ATCC}\right.$ BAA $-1485^{\mathrm{T}}=\mathrm{DSM}$ $\left.19004^{\mathrm{T}}\right)$, was isolated from the rectum of a horse with oligofructose-induced laminitis.

\section{Acknowledgements}

This project was supported by the Rural Industries Research and Development Corporation (RIRDC) of Australia and the Animal Health Foundation (AHF), St Louis, MO, USA. We would like to acknowledge the assistance provided by Dr Tom Stevenson of The University of Queensland's School of History, Philosophy, Religion and Classics and Dr Jean Euzéby of the École Nationale Vétérinaire (Toulouse) in selecting the specific epithets for the micro-organisms described in this paper. We would also like to thank Dr Margaret Henry for her permission to name the bacterium $S$. henryi in honour of her late husband Dr Dick Peter Henry.

\section{References}

Bjornsson, L., Hugenholtz, P., Tyson, G. W. \& Blackall, L. L. (2002). Filamentous Chloroflexi (green non-sulfur bacteria) are abundant in wastewater treatment processes with biological nutrient removal. Microbiology 148, 2309-2318.

Burrell, P. C., Keller, J. \& Blackall, L. L. (1998). Microbiology of a nitrite-oxidizing bioreactor. Appl Environ Microbiol 64, 1878-1883.

Chatellier, S., Harel, J., Zhang, Y., Gottschalk, M., Higgins, R., Devriese, L. A. \& Brousseau, R. (1998). Phylogenetic diversity of Streptococcus suis strains of various serotypes as revealed by $16 \mathrm{~S}$ rRNA gene sequence comparison. Int J Syst Bacteriol 48, 581-589.

Facklam, R. (2002). What happened to the streptococci: overview of taxonomic and nomenclature changes. Clin Microbiol Rev 15, 613-630.

Garner, H. E., Coffman, J. R., Hahn, A. W., Hutcheson, D. P. \& Tumbleson, M. E. (1975). Equine laminitis of alimentary origin: an experimental model. Am J Vet Res 36, 441-444.

Garner, H. E., Moore, J. N., Johnson, J. H., Clark, L., Amend, J. F., Tritschler, L. G., Coffmann, J. R., Sprouse, R. F., Hutcheson, D. P. \& Salem, C. A. (1978). Changes in the caecal flora associated with the onset of laminitis. Equine Vet J 10, 249-252.

Hoshino, T., Fujiwara, T. \& Kilian, M. (2005). Use of phylogenetic and phenotypic analyses to identify nonhemolytic streptococci isolated from bacteremic patients. J Clin Microbiol 43, 6073-6085.

Kilpper-Bälz, R. \& Schleifer, K. H. (1987). Streptococcus suis sp. nov., nom. rev. Int J Syst Bacteriol 37, 160-162.

Lane, D. J. (1991). 16S/23S rRNA sequencing. In Nucleic Acid Techniques in Bacterial Systematics, pp. 115-175. Edited by E. Stackebrandt \& M. Goodfellow. New York: Wiley.

Mesbah, M., Premachandran, U. \& Whitman, W. B. (1989). Precise measurement of the $\mathrm{G}+\mathrm{C}$ content of deoxyribonucleic acid by highperformance liquid chromatography. Int J Syst Bacteriol 39, 159-167.

Milinovich, G. J., Trott, D. J., Burrell, P. C., van Eps, A. W., Thoefner, M. B., Blackall, L. L., Al Jassim, R. A., Morton, J. M. \& Pollitt, C. C. (2006). Changes in equine hindgut bacterial populations during oligofructose-induced laminitis. Environ Microbiol 8, 885-898.

Milinovich, G. J., Trott, D. J., Burrell, P. C., Croser, E. L., Al Jassim, R. A., Morton, J. M., van Eps, A. W. \& Pollitt, C. C. (2007). Fluorescence in situ hybridization analysis of hindgut bacteria associated with the development of equine laminitis. Environ Microbiol 9, 2090-2100.

Pollitt, C. C. (1996). Basement membrane pathology: a feature of acute equine laminitis. Equine Vet J 28, 38-46.

Pollitt, C. C. (1999). Equine laminitis: a revised pathophysiology. In Proceedings of the 45th Annual Convention of the American Association of Equine Practitioners, pp. 188-192. Albuquerque, NM: American Association of Equine Practitioners.

Poyart, C., Quesne, G., Coulon, S., Berche, P. \& Trieu-Cuot, P. (1998). Identification of streptococci to species level by sequencing the gene encoding the manganese-dependent superoxide dismutase. J Clin Microbiol 36, 41-47.

Poyart, C., Quesne, G. \& Trieu-Cuot, P. (2002). Taxonomic dissection of the Streptococcus bovis group by analysis of manganese-dependent superoxide dismutase gene $(\operatorname{sod} A)$ sequences: reclassification of 'Streptococcus infantarius subsp. coli' as Streptococcus lutetiensis sp. 
nov. and of Streptococcus bovis biotype 11.2 as Streptococcus pasteurianus sp. nov. Int J Syst Evol Microbiol 52, 1247-1255.

Schlegel, L., Grimont, F., Ageron, E., Grimont, P. A. \& Bouvet, A. (2003). Reappraisal of the taxonomy of the Streptococcus bovis/ Streptococcus equinus complex and related species: description of Streptococcus gallolyticus subsp. gallolyticus subsp. nov., S. gallolyticus subsp. macedonicus subsp. nov. and S. gallolyticus subsp. pasteurianus subsp. nov. Int J Syst Evol Microbiol 53, 631-645.

Schlegel, L., Grimont, F., Grimont, P. A. \& Bouvet, A. (2004). New group D streptococcal species. Indian J Med Res 119 (Suppl.), 252-256.

Stackebrandt, E. \& Charfreitag, O. (1990). Partial 16S rRNA primary structure of five Actinomyces species: phylogenetic implications and development of an Actinomyces israelii-specific oligonucleotide probe. J Gen Microbiol 136, 37-43.
Stackebrandt, E. \& Goebel, B. M. (1994). Taxonomic note: a place for DNA-DNA reassociation and $16 \mathrm{~S}$ rRNA sequence analysis in the present species definition in bacteriology. Int J Syst Bacteriol 44, 846-849.

Swan, A. (1954). The use of a bile-aesculin medium and of Maxted's technique of Lancefield grouping in the identification of enterococci (group D streptococci). J Clin Pathol 7, 160-163.

Tarradas, C., Arenas, A., Maldonado, A., Luque, I., Miranda, A. \& Perea, A. (1994). Identification of Streptococcus suis isolated from swine: proposal for biochemical parameters. J Clin Microbiol 32, 578-580.

USDA (2000). Lameness and Laminitis in US Horses. Fort Collins, CO: USDA:APHIS:VS, CEAH, National Animal Health Monitoring System.

van Eps, A. W. \& Pollitt, C. C. (2006). Equine laminitis induced with oligofructose. Equine Vet J 38, 203-208. 